\title{
The Chromosome Male Germ Cell Biology in Health and Diseases
}


This page intentionally left blank 


\section{The 3 chromosome and \\ Male Germ Cell Biology \\ in Health and Diseases}

\section{Noworld Scientific}




\section{Published by}

World Scientific Publishing Co. Pte. Ltd.

5 Toh Tuck Link, Singapore 596224

USA office: 27 Warren Street, Suite 401-402, Hackensack, NJ 07601

UK office: 57 Shelton Street, Covent Garden, London WC2H 9HE

\section{British Library Cataloguing-in-Publication Data}

A catalogue record for this book is available from the British Library.

\section{THE Y CHROMOSOME AND MALE GERM CELL BIOLOGY IN HEALTH AND DISEASES}

Copyright (C) 2007 by World Scientific Publishing Co. Pte. Ltd.

All rights reserved. This book, or parts thereof, may not be reproduced in any form or by any means, electronic or mechanical, including photocopying, recording or any information storage and retrieval system now known or to be invented, without written permission from the Publisher.

For photocopying of material in this volume, please pay a copying fee through the Copyright Clearance Center, Inc., 222 Rosewood Drive, Danvers, MA 01923, USA. In this case permission to photocopy is not required from the publisher.

ISBN-13 978-981-270-374-3

ISBN-10 981-270-374-8

Typeset by Stallion Press

Email: enquiries@stallionpress.com

Printed in Singapore. 


\title{
FOREWORD
}

\author{
Owen M. Rennert \\ Scientific Director, \\ National Institute of Child Health and Human Development, \\ National Institutes of Health
}

\begin{abstract}
For the real amazement, if you wish to be amazed, is this process. You start out as a single cell derived from the coupling of a sperm and an egg; this divides into two, then four, then eight, and so on, and at a certain stage there emerges a single cell which has as all its progeny the human brain. The mere existence of such a cell should be one of the great astonishments of the earth. People ought to be walking around all day, all through their waking hours calling to each other in endless wonderment, talking of nothing except that cell. ${ }^{\mathrm{a}}$
\end{abstract}

This book focuses on the development of one progenitor in the "amazing process" described so eloquently by Lewis Thomas — the biology of spermatogenesis. It examines a model stem cell system, and attempts to formulate a series of fundamental questions:

1. What are the genetic regulatory events that determine progression from a primordial (stem) cell that curtails cell proliferation and initiates a process of differentiation that gives rise to spermatozoa?

2. What is the genetic machinery operative during meiosis and mitosis?

3. What are some of the trophic factors within the cell's environment/niche that initiate or drive this process?

4. What are the temporal changes in the transcriptome and proteosome that regulate the process of spermatogenesis?

5. How do these biological processes modulate or affect reproduction and malignant transformation, and can one develop new strategies based on this new information to apply to the management of reproductive failure, etc.?

${ }^{a}$ Lewis Thomas (1979), cited in Scott Gilbert (2006), Developmental Biology, Sinauer Associates Inc., Sunderland, MA, p. 152. 
The first six chapters of this volume focus on Y chromosome-specific factors/functions, and on the role of the $\mathrm{X}$ chromosome and some of the autosomes during spermatogenesis. The investigators present data on both normal spermatogenesis as well as infertility associated with arrested/defective spermatogenesis.

Chapters 7 through 9 present new data and highlight the functions of various growth factors and initiation factors, and the mechanisms of transcriptional regulation that modify or control the process of spermatogenesis. Chapters 10-12 discuss the application of new technologies to study spermatogenesis: in vitro spermatogonial stem cell models, transplantation of germ cells and testicular tissue, and novel approaches for initiation of fertilization in mammals.

The final two chapters present the results of investigations of testicular germ cell tumors and the origin of germ cell neoplasia. They identify potential gene targets that modulate these processes, and discuss the interaction of gene polymorphisms with the environment and their potential importance in neoplastic transformation.

The research presented in this book focuses on one central theme those factors that regulate cell fate; how a cell's destiny either to proliferate or to differentiate is determined. Spermatogenesis may serve as a model system to investigate this fundamental phenomenon.

"Research is to see what everybody else has seen, and to think what nobody else has thought." 


\section{CONTENTS}

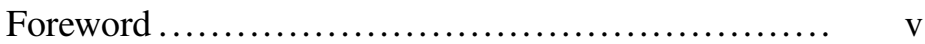

Owen M. Rennert

Chapter 1 The roles of mouse Y chromosome genes in spermatogenesis ...............................

Paul S. Burgoyne and Michael J. Mitchell

Chapter 2 Male meiotic sex chromosome inactivation and meiotic silencing............................. 27

James M. A. Turner and Paul S. Burgoyne

Chapter 3 Insights into $S R Y$ action from sex reversal mutations .......................................

Melissa I. Stahle, Pascal Bernard, and Vincent R. Harley

Chapter 4 The TSPY gene family Yun-Fai Chris Lau, Tatsuo Kido, and Yunmin Li

Chapter 5 Structure and function of AZFa locus in human spermatogenesis........................ 91 Peter H. Vogt, Hans-Juergen Ditton, Christine Kamp, and Jutta Zimmer

Chapter $6 \quad R B M Y$ and $D A Z$ in spermatogenesis Pauline Yen

Chapter 7 Neurotrophic factors in the development of the postnatal male germ line Marie-Claude Hofmann and Laura Braydich-Stolle 
Chapter 8 Dickkopf-like $1-$ a protein unique to mammals that is associated both with formation of trophoblast stem cells and with spermatogenesis

Matthew J. Kohn, Kotaro J. Kaneko, Rieko Yagi, Eveline S. Litscher, Paul M. Wassarman, and Melvin L. DePamphilis

Chapter 9 Antisense transcription in developing male germ cells. 201 Wai-Yee Chan, Shao-Ming Wu, Lisa Ruszczyk, Tin-Lap Lee, and Owen M. Rennert

Chapter 10 The spermatogonial stem cell model Martin Dym and Zuping He

Chapter 11 Transplantation of germ cells and testis tissue 235 Ina Dobrinski

Chapter 12 Orthodox and unorthodox ways to initiate fertilization and development in mammals Ryuzo Yanagimachi

Chapter 13 Pathogenesis of testicular germ cell tumors 263 Leendert H. J. Looijenga

Chapter 14 Origin of testicular germ cell neoplasia: the role of sex chromosomes

Ewa Rajpert-De Meyts, Anne Marie Ottesen,

Christina Hoei-Hansen, Si Brask Sonne, Henrik

Leffers, and Niels E. Skakkebak

Author Index

Index 